\title{
Validity Evidences for the Dimensional Clinical Personality Inventory in Outpatient Psychiatric Sample ${ }^{1}$
}

\author{
Roberta Katz Abela ${ }^{2}$ \\ Universidade Federal de São Paulo, \\ São Paulo-SP, Brazil \\ Sabrina Jisun Myung Cho \\ Universidade Federal de São Paulo, \\ São Paulo-SP, Brazil
}

\author{
Lucas de Francisco Carvalho \\ Universidade São Francisco, \\ Itatiba-SP, Brazil \\ Latife Yazigi \\ Universidade Federal de São Paulo, \\ São Paulo-SP, Brazil
}

\begin{abstract}
The Dimensional Clinical Personality Inventory (IDCP) was developed in Brazil for the assessment of pathological personality traits. This study aimed to seek validity evidence for the dimensions of IDCP based on external criteria, psychiatric diagnosis. We examined the profile in IDCP of 105 psychotherapy outpatients, previously diagnosed with personality disorders. The profiles were compared with the profile of the normative non-clinical sample and we conducted the repeated measures analysis to investigate whether the IDCP is able to discriminate consistent profiles for different diagnoses and compared the general population. The results suggest validity evidence based on external criteria for the IDCP dimensions and points to the clinical effectiveness of the instrument.
\end{abstract}

Keywords: personality inventory, personality traits, personality disorders, psychological assessment, psychological testing

\section{Evidências de Validade do Inventário Dimensional Clínico da Personalidade em Amostra Psiquiátrica}

\begin{abstract}
Resumo: Foi desenvolvido no Brasil o Inventário Dimensional Clínico da Personalidade (IDCP) para avaliação das características patológicas da personalidade. O presente estudo buscou evidências de validade com base em critério externo, diagnóstico psiquiátrico, das dimensões do IDCP. Examinou-se o perfil no IDCP de 105 pacientes de ambulatório de psicoterapia, previamente diagnosticados com transtornos da personalidade. Comparou-se o perfil no IDCP da amostra clínica com o perfil da amostra normativa não clínica e realizou-se o procedimento de análise de perfis por medidas repetidas visando investigar se o IDCP é capaz de discriminar perfis coerentes para os distintos diagnósticos e em comparação à população geral. Os resultados sugerem evidências de validade com base no critério externo para as dimensões do IDCP, bem como aponta para a utilidade clínica do instrumento.
\end{abstract}

Palavras-chave: inventário da personalidade, traços de personalidade, distúrbios da personalidade, avaliação psicológica, testes psicológicos

\section{Evidencias de Validez del Inventario Dimensional Clínico de Personalidad en Muestra Psiquiátrica}

\begin{abstract}
Resumen: El Inventario Dimensional Clínico del Personalidad (IDCP) fue desarrollado en Brasil para evaluación del el IDCP prueba. Este estudio tuvo como objetivo buscar evidencias de validez en base a criterios externos, diagnóstico psiquiátrico, a un instrumento para la evaluación de los trastornos de personalidad típica síntomas, el IDCP. Examinamos el perfil en IDCP de 105 pacientes de la clínica de psicoterapia, previamente diagnosticados con trastornos de la personalidad. Los perfiles se compararon con el perfil de la muestra no clínica normativa y que se llevó a cabo el análisis de medidas repetidas para investigar si el IDCP es capaz de discriminar los perfiles consistentes para diferentes diagnósticos en comparación con la población general. Los resultados sugieren evidencia de validez sobre la base de criterios externos a dimensiones del IDCP y puntos para la utilidad clínica del instrumento.
\end{abstract}

Palabras clave: inventario de personalidad, rasgos de personalidad, trastornos de la personalidad, evaluación psicológica, tests psicológicos

Since ancient times people have been classified regarding types of personality and their disorders (Andreasen \& Black,

1 Article derived from the master's thesis of the first author under the supervision of the last, defended in 2003 at the Graduate Program in Psychiatry and Medical Psychology of the Universidade Federal de São Paulo.

Support: National Council for Scientific and Technological Development (CNPq - Process no.138535/2011-6).

2 Correspondence address:

Roberta Katz Abela. Department of Psychiatry. Medical School of the Federal University of São Paulo, Rua Borges Lagoa, 570, $1^{\circ}$ andar. CEP 04038-020. São Paulo-SP, Brazil. E-mail: rokatz@uol.com.br
2009). Hippocrates related temperaments to the bodily humors to describe types of people. At the beginning of the XIX century, Pinel was the first to distinguish personality disorder from mental illness, describing bizarre behaviors in the absence of other characteristics of mental disorder, which he called manie sans delire. At the beginning of the twentieth century, Kraepelin proposed an unsystematic classification, describing the types: unstable, irritable, impulsive, eccentric, liars, disputers, and anti-social and Schneider defined 
abnormal personalities as ways of being, distinguishing them from the field of diseases (Del Porto, 1996).

The classification of mental disorders was systematized and published in the first edition of the Diagnostic and Statistical Manual of Mental Disorders, DSM (American Psychiatric Association [APA], 1952). The second edition of DSM (APA, 1968) established twelve categories of PD that were reformulated during the successive editions of the Manual. In the third edition of DSM (APA, 1980), the PD were organized on a separate axis from the clinical disorders, and from the third edition revised, DSM-III-R (APA, 1987), the prevalence of two or more diagnostic categories started to be known as comorbidity (Alvarenga, Flores-Mendoza, \& Gontijo, 2009).

For the fifth and latest edition of the DSM (APA, 2013), it was suggested the dimensional approach to evaluation and classification of PDs (Hopwood, 2011; Hopwood, Thomas, Markon, Wright, \& Krueger, 2012; Krueger, Derringer, Markon, Watson, \& Skodol, 2012; Krueger \& Eaton, 2010; Krueger et al., 2011). It was considered, however, that the dimensional model would be complex for clinical practice (Widiger, 2011; Zimmerman, 2012), so it was not included on the main body of DSM-5, but on the third section of the Manual, for further studies. Therefore, the diagnosis according to the DSM, currently, should be performed based on section 2, which maintains the model used in the previous edition.

The categorical perspective, such as presented in DSMIV-TR (American Psychiatric Association [APA], 2002), which remains in force in the DSM until today, sees PDs as distinct qualitative clinical syndromes; however, the clinical situations have shown that there are no clear limits between the different pathological aspects of personality (Hopwood et al., 2011; Millon, Millon, Meagher, Grossman, \& Ramnath, 2004; Oldham et al., 1992; Widiger \& Samuel, 2005).

The validity and the practical reliability of the diagnostic categories of PDs proposed by the DSM have been discussed (Brown \& Barlow, 2005; Kupfer, First, \& Regier, 2002) and the main limitations described regarding the categorical model are: an excessive diagnostic of comorbidity; an inadequate coverage of PDs; an arbitrary and unstable limitation with the healthy personality functioning; an heterogeneity between individuals who share the same diagnostic criteria; and, an inadequate scientific basis for certain diagnostic categories (Bornstein, 2011; First et al., 2004; Widiger \& Trull, 2007; Zimmerman, 2012).

Therefore, several instruments for evaluation of the symptoms typical of PDs have been proposed (Krueger et al., 2012), so that all people are evaluated for all symptoms and must have a profile that may be more or less similar to the one proposed by the DSM-IV-TR and DSM-5 regarding the symptoms composing each diagnostic category (Skodol, Bender et al., 2011; Skodol, Clark, et al., 2011). In Brazil, Carvalho and Primi (2015) developed the Dimensional Clinical Personality Inventory (Inventário Dimensional Clínico da Personalidade - IDCP), based on the diagnostic criteria for the PDs described in DSM-IV-TR (APA, 2002) and, therefore, in section 2 of the DSM-5 (APA, 2013), as well as in the typical conditions of each PD such as presented by Millon (2011).

This is a self-report instrument for assessing pathological aspects of personality, consisting of 163 items distributed in 12 dimensions, namely: Dependency, Aggressiveness, Mood Instability, Eccentricity, Need for Attention, Distrust, Grandiosity, Isolation, Avoidance of Criticism, Self-Sacrifice, Conscientiousness, and Impulsivity. It is noteworthy that each dimension has more to do with a given PD (Carvalho \& Primi, 2015).

In the present study, we applied the IDCP in an outpatient psychiatric sample previously diagnosed with a PD. We sought to identify criterion validity evidence for the IDCP (Urbina, 2007) and to extend the investigations on the dimensional approach for the diagnosis of PD. For this study, we selected the four most prevalent categories of PD in the sample studied, the subgroups: Avoidant, Paranoid, Borderline, and Dependent. Their profiles in the 12 dimensions of the IDCP are presented and discussed below. This study also discussed the relationship between comorbidity and severity of PD.

\section{Method}

\section{Participants}

The study sample consisted of 105 participants from an outpatient psychotherapy service at a University Hospital, $78 \%$ of which were women, aged between 19 and 73 years $(M=39.9, S D=12.8)$, who presented between 1 and 13 years of education (47.6\% of participants with high school and $34.3 \%$ with higher education or graduation). Of the total sample, 88 met the criteria for at least one PD, as follows: 52 avoidant, 31 paranoid, 30 borderline, 21 dependent, 20 obsessive-compulsive, 14 histrionic, 11 narcissistic, 8 schizotypal, 5 schizoid, 3 antisocial. In addition, it is noteworthy that the majority of the sample $(n=100)$ presented an Axis I psychiatric disorder, as follows: 82 with mood disorder, 60 with anxiety disorder, 9 diagnosed with substance use/abuse, 7 with somatoform disorders, and 6 with eating disorders.

The study included all the individuals who were under treatment during the data collection period of this study, and which comprised a non-probabilistic clinical convenience sample (Patton, 2002). Inclusion criteria in the sample were those defined by the team of psychotherapists, namely: minimum age of 18 years, motivation and willingness to attend weekly psychotherapy sessions; the exclusion criteria were presenting schizophrenic disorders, dementia disorders, or mental retardation.

\section{Instruments}

Structured Clinical Interview - SCID-II (First, Gibbon, Spitzer, Williams, \& Benjamin, 1997/2008). This 
is a semi-structured interview for Axis II diagnoses of the DSM-IV (APA, 1995). SCID-II consists of 119 items for the investigation of the twelve diagnostic categories of Personality Disorder described in The Manual: Avoidant PD, Dependent PD, Obsessive-Compulsive PD, Paranoid PD, Schizotypal PD, Schizoid PD, Histrionic PD, Narcissistic PD, Borderline PD, Passive-Aggressive PD, and Depressive PD.

Dimensional Clinical Personality Inventory (IDCP). Self-report inventory for the evaluation of pathological personality traits (Carvalho, 2014), built by Carvalho and Primi (2015). Such as previously reported, the instrument consists of 163 items distributed in 12 dimensions. The psychometric properties of the instrument were verified in studies conducted by Carvalho and Primi (2015), Carvalho, Oliveira Filho, Pessotto and Bortolotti (2014) and Carvalho, Primi and Stone (2014), for evidence of validity based on the internal structure and internal consistency reliability indices, Carvalho and Primi (in press), for evidence of validity based on external criteria (NEO-PI-R), and related with other constructs (Miguel, Finoto, \& Miras, 2013).

\section{Procedure}

Data collection. The instruments were applied at the outpatient psychotherapy clinic of the University Hospital in previously scheduled time. The IDCP was applied either individually or in groups, in sessions that lasted approximately one hour. Trained psychiatrists have applied the SCID in a single session or two sessions lasting approximately one hour each.

Data analysis. After collection, the data were tabulated and we performed a descriptive statistical analysis of the sample and variance analyses, which are called Profile Analysis of Repeated Measures (Tabachnick \& Fidell, 2007), using the SPSS program.

\section{Ethical Considerations}

The project that supported this research was subjected and approved by the Research Ethics Committee of Universidade Federal de São Paulo (Protocol CEP 1293/11). The participants were able to participate only after the agreement on the procedures and the Informed Consent were signed.

\section{Results}

The results raised through the SCID-II of DSM-IV indicated that 88 of the 105 individuals evaluated are diagnosed with a PD, which is equivalent to a prevalence of $83.8 \%$ of PDs in the sample. Among the 88 individuals with PDs, $28.4 \%$ have one diagnosis of PD; $22.7 \%$ have two comorbid diagnoses of PD, and $48.9 \%$ have more than two comorbid diagnoses of PD. That is, most of the subjects diagnosed with PD in this sample, present comorbidity. The most prevalent disorders in this sample are: Avoidant (59.8\%), Paranoid (35.6\%), Borderline (34.5\%), and
Dependent $(24.1 \%)$. The profiles on the IDCP of these groups have been investigated and are shown below. We also compared the IDCP profiles in the groups composed of participants: without PD $(n=17)$, with PD in a single diagnostic category $(n=25)$, and with comorbid diagnoses $(n=63)$; the results are described below.

The IDCP scores presented in this study, developed in a clinical sample, were standardized based on the non-clinical sample of the study by Carvalho and Primi (2015), according to the $\mathrm{T}$ score, so that the average has been standardized in 50 and the standard deviation in 10 for the 12 dimensions of the instrument. We considered the results above one $S D$ of the normative mean $(M \geq 60)$ or below one $S D(M \leq 40)$ as indicative of clinical significance.

The procedure of Analysis of Repeated Measures allowed the comparison of the profile of each diagnostic group with the profile of the other participants and to verify whether the IDCP is able to discriminate the different PD categories of the DSM-IV (Figures 1 to 4 ).

\section{Avoidant Profile}

In the comparison between the profile of the Avoidant group without comorbidities $(n=10)$, the profile of the Avoidant Group with associated comorbidities $(n=42)$, and the profile of the other participants of the sample diagnosed with PD who did not present the diagnosis $(n=35)$, the difference observed between the profiles was statistically significant regarding the 12 dimensions of the $\operatorname{IDCP}(\{F=3.93$; $p=.001\})$. As shown in Figure 1, participants with Avoidant PD without other comorbidities presented more expressive and discrepant scores in the dimensions Criticism Avoidance (F9; $\mathrm{d}_{\text {avoidant comorbidity*avoidant without comorbidity }}=0.48$ and $\mathrm{d}_{\text {avoidant }}$ without comorbidity*non-avoidant $=0.55$ ) and Need for Attention (F5; $d_{\text {avoidant comorbidity*avoidant without }}$ comorbidity $=0.11$ and $\mathrm{d}_{\mathrm{avoidant}}$ without comorbidity* non-avoidant $=0.30$ ), especially in the comparison avoidant and non-avoidant, pointing to the accentuated belief of incapacity, humiliation and criticism by others, and reduced need for attention. Avoidant participants with other comorbid diagnoses of PD (being the main ones: Paranoid, 42.3\%; Borderline, 36.5\% and Dependent, 26.9\%) presented a more complex profile, characterized by more severity in the other six dimensions: Dependence $\left(\mathrm{F} 1 ; \mathrm{d}_{\mathrm{avoidant}}\right.$ comorbidity*avoidant without comorbidity $=0.42$ and $\mathrm{d}_{\text {avoidant }}$ comorbidity* non-avoidant $=0.77)$, Mood Instability (F3; $\mathrm{d}_{\text {avoidant comorbidity*avoidant without comorbidity }}=0.97$ and $\left.\mathrm{d}_{\text {avoidant comorbidity*non-avoidant }}=0.54\right)$, Eccentricity $(\mathrm{F} 4$; $\mathrm{d}_{\text {avoidant comorbidity*avoidant without comorbidity }}=0.90$ and $\mathrm{d}_{\mathrm{avoidant}}$ comorbidity*non-avoidant $\left.=0.90\right)$, Distrust $(\mathrm{F} 6$; $\mathrm{d}_{\mathrm{avoidant}}$ comorbidity*avoidant without comorbidity $=0.75$ and $\mathrm{d}_{\mathrm{avoidant}}$ comorbidity*non-avoidant $\left.=0.52\right)$, Isolation ( $\mathrm{F} 8$; $\mathrm{d}_{\mathrm{avoidant}}$ comorbidity*avoidant without comorbidity $=0.82$ and $\mathrm{d}_{\text {avoidant comorbidity*non-avoidant }}=0.32$ ), and Self-sacrifice (F10; $\mathrm{d}_{\text {avoidant comorbidity*avoidant without comorbidity }}=0.72$ and $1 \mathrm{~d}_{\text {avoidantcomorbidity*non-avoidant }}=0.54$ ), withexpressive 


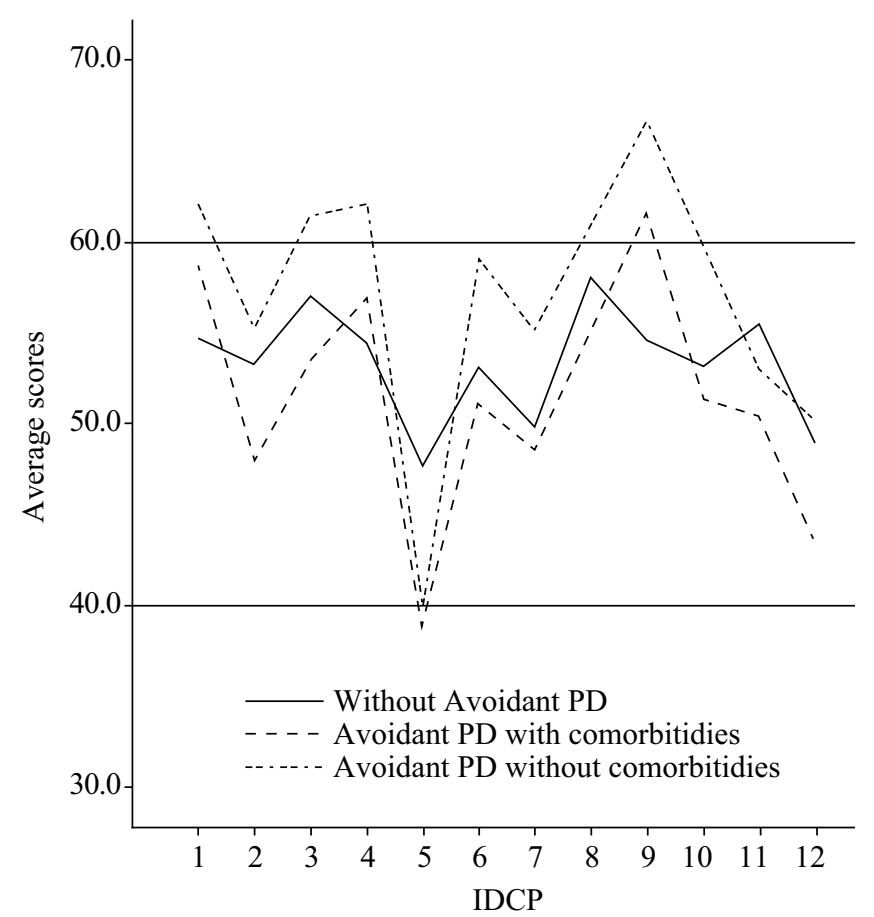

Figure 1. Profile of groups Avoidant without comorbidity, Avoidant with comorbidity and non-Avoidant. Note. $\mathrm{F} 1$ = Dependence; F2 = Aggressiveness; F3 = Mood Instability; F4 = Eccentricity; F5 = Need for Attention; F6 = Distrust $; \mathrm{F} 7=$ Grandiosity $; \mathrm{F} 8=$ Isolation $; \mathrm{F} 9=$ Criticism Avoidance; F10 = Self-sacrifice; F11 = Conscientiousness; F12 = Impulsivity.

differences in all cases. These dimensions are conceptually more relevant in the comorbid disorders associated to the Avoidant PD in the sample analyzed. The dimensions Avoidance of Criticism (F9) and Dependence (F1), intense in the avoidant profile without comorbidities showed even more severe in the avoidant profile with associated comorbidities, pointing to a greater severity in pathologies characterized by diagnostic comorbidity.

\section{Paranoid Profile}

Comparing the Paranoid $(n=31)$ profile and the profile of other participants who did not present the diagnosis of Paranoid PD $(n=56)$, in the 12 dimensions of IDCP, the observed difference was not statistically significant $(\{F=1.42 ; p=.19\})$. The Paranoid group presented comorbidities with the Avoidant (70.9\%), Borderline (51.6\%), Dependent (25.8\%), and Schizotypal (22.6\%) disorders that possibly contributed to the increase in the dimensions Avoidance of Criticism (F9), Mood Instability (F3), Dependence (F1), Eccentricity (F4), and Isolation (F8). The quantitative analysis of Figure 2 points that the more expressive scores and the more discrepant from the Paranoid occurred in the following dimensions: Distrust (F6; $d=0.79$ ); Eccentricity (F4; $d=0.65$ ); Isolation (F8; $d=0.50)$ and Mood Instability (F3;

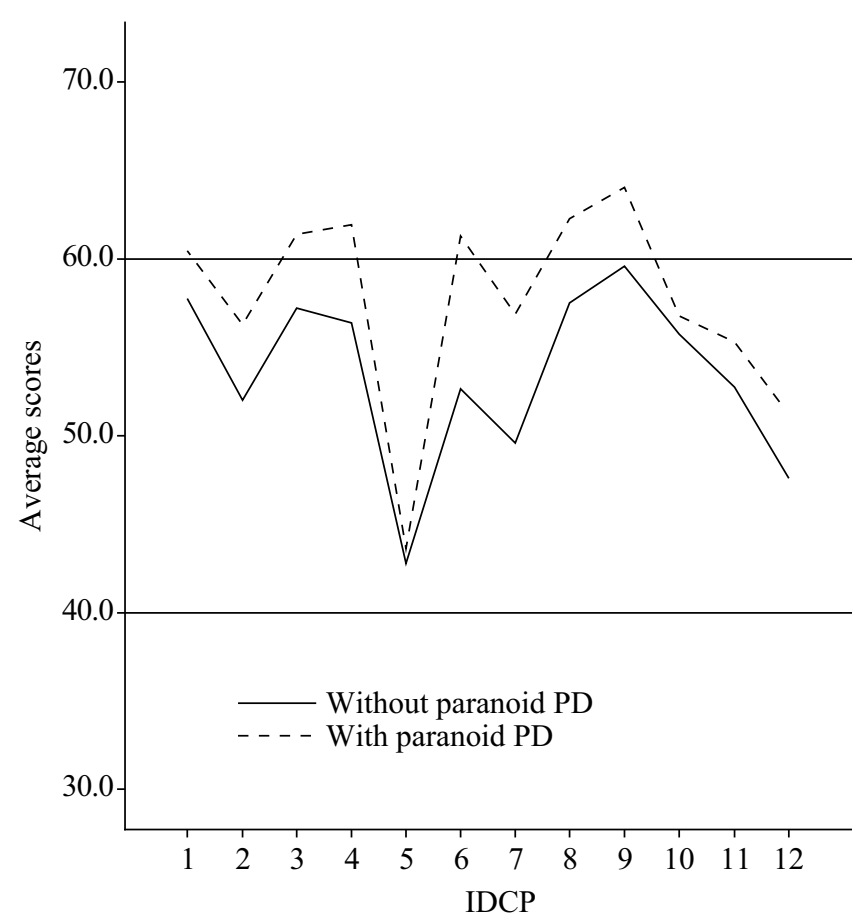

Figure 2. Graphic comparing the profiles of Paranoid and non-Paranoid groups.

$d=0.48)$. The dimensions Grandiosity (F7; $d=0.69)$ and Aggressiveness (F2; $d=0.48)$, despite presenting a bigger discrepancy between the Paranoid and the non-Paranoid profile, were not expressive for this sample, i.e., with a score near the mean 50. In turn, the dimension Avoidance of Criticism (F9) was more intense in this sample, but was also intense in the non-Paranoid, not discriminating the Paranoid and the non-Paranoid profiles.

\section{Borderline Profile}

In the comparison between the profile of the Borderline $(n=30)$ group and the profile of other participants who did not present a diagnosis of PD Borderline $(n=57)$, in the 12 dimensions of IDCP, the difference between the profiles was not statically significant $(\{F=1.54 ; p=.15\})$. In a quantitative analysis of Figure 3 we may observe that participants with Borderline PD presented in the IDCP a profile with more expressive and discrepant scores in the dimensions: Mood Instability (F3; $d=0.96$ ); Eccentricity (F4; $d=0.68)$, and Isolation (F8; $d=0.51)$. The dimensions Impulsivity (F12; $d=0.60)$; Grandiosity (F7; $d=0.51$ ) and Aggressiveness (F2; $d=0.58$ ) were discrepant in the Borderline profile, although they were not much intense. The Avoidance of Criticism dimension was virtually as intense in this sample as in the non-Borderlines. The main comorbidities with the Borderline PD were: Avoidant PD (63.3\%) and Paranoid (53.3\%), possibly contributing to the increase in the dimensions Avoidance of Criticism (F9) and Distrust (F6) in the Borderline profile. 


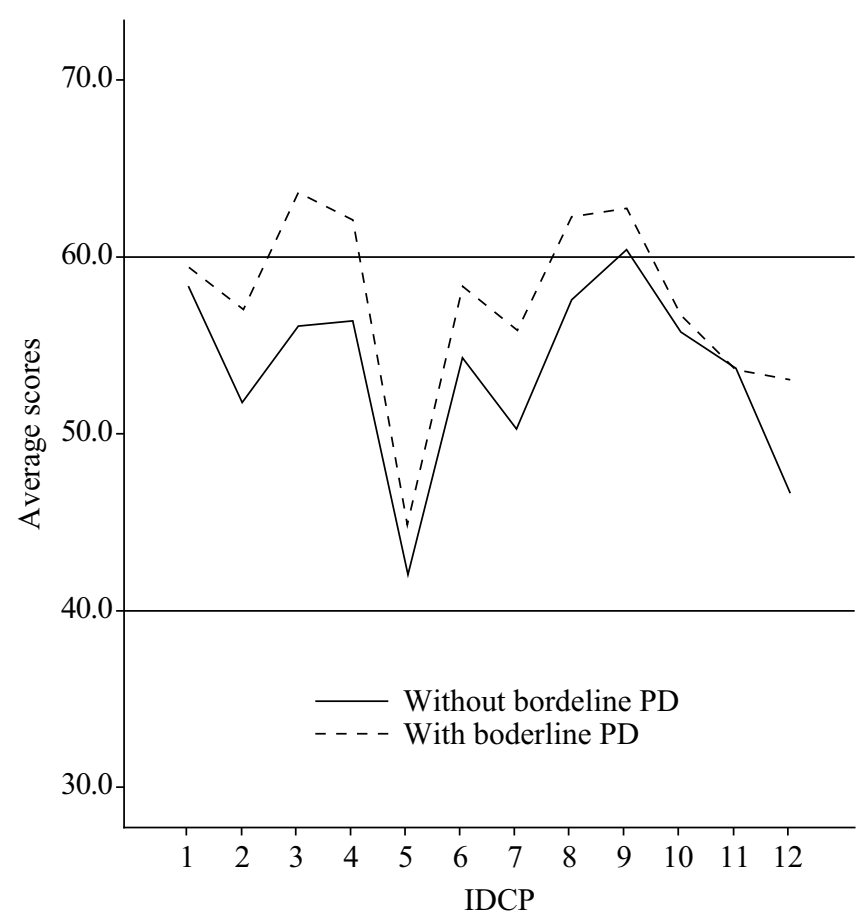

Figure 3. Graph comparing the profiles of the Borderline and non-Borderline groups.

\section{Dependent Profile}

The profile of the Dependent group $(n=21)$ was compared with the profile of other participants who did not present the Dependent diagnosis PD $(n=66)$. The difference between the profiles was statistically significant regarding the 12 dimensions of the $\operatorname{IDCP}(\{F=2.11 ; p=.04\})$. Figure 4 illustrates that the participants with Dependent PD presented intense Avoidance of Criticism (F9; $d=0.58)$, Dependence $(\mathrm{F} 1 ; d=0.82)$, Self-sacrifice (F10; $d=0.64)$, Eccentricity $(\mathrm{F} 4 ; d=0.36)$ and Mood Instability (F3; $d=0.28)$, and the dimensions that most discriminated this group from the others in the IDCP were: Dependence (F1) and Self-sacrifice (F10). The intensification of dimensions Eccentricity (F4) and Mood Instability (F3) may be explained by the comorbidity of Dependent PD with Paranoid (38\%) and Borderline (28,5\%) disorders. Despite moderately isolated, the Dependent PD showed less tendency towards Isolation than the non-Dependent.

\section{Presence and Quantity of PDs}

The profile of the following groups were compared: without diagnosis of $P D(n=17)$, with diagnosis of $P D$ in a single diagnostic category $(n=25)$, with diagnosis of $P D$ in two diagnostic categories $(n=20)$ and with diagnosis of $P D$ in more than two diagnostic categories $(n=43)$. Regarding the 12 dimensions of the IDCP, the difference between the profiles was not statistically significant $(\{\mathrm{F}=1.39 ; p=.11\})$. The quantitative analysis of Figure 5 indicated that the presence of multiple diagnoses of PD is related with the

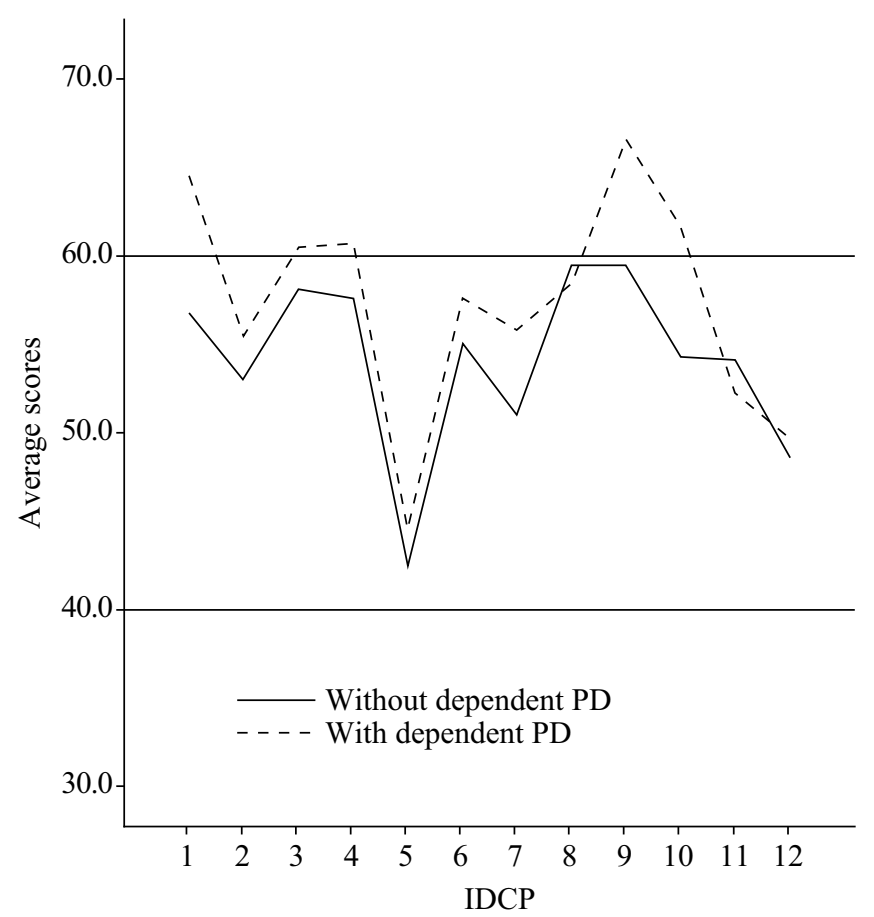

Figure 4. Graph comparing the profile of the Dependent and non-Dependent groups.

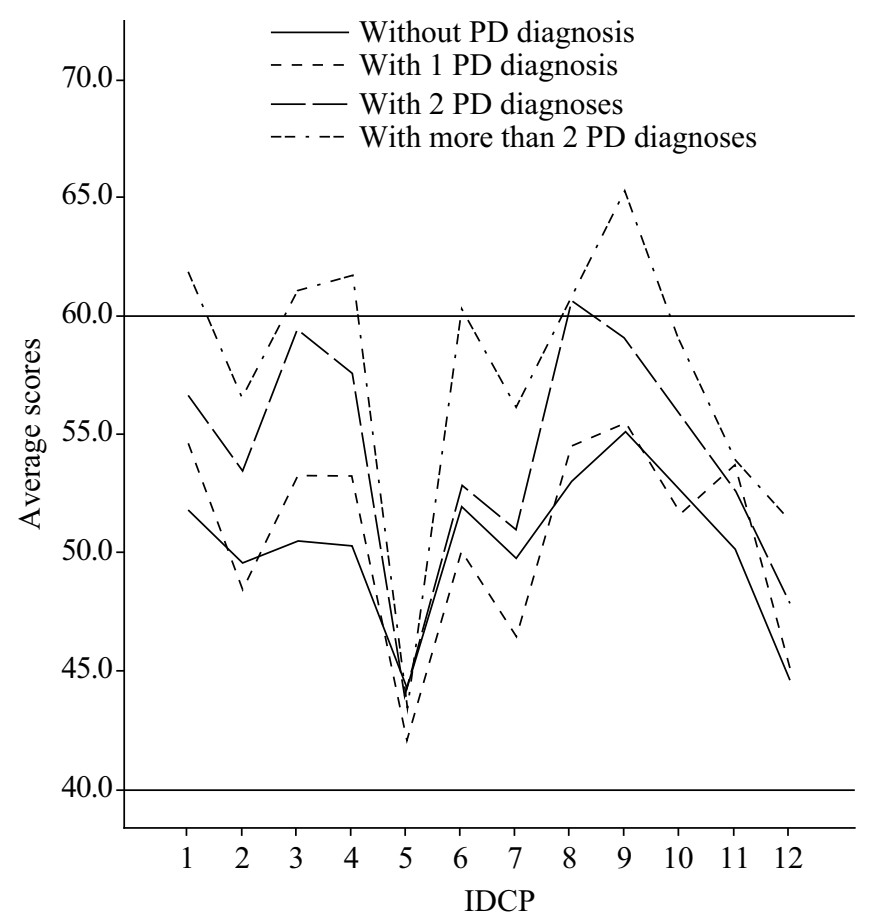

Figure 5. Graph comparing the profile of the groups with one diagnosis of PD, those with two or more diagnoses of PD, and the group without diagnosis of PD.

greater number of dimensions of personality that reach levels of functioning, confirming the evidences illustrated on the Avoidant group (Figure 1) that the more comorbid diagnoses, the more severe the functioning of personality. 


\section{Discussion}

The results of this study indicated that after comparing the IDCP profile in the clinical sample with PDs, with the profile of the non-clinical normative sample, using the profile analysis by repeated measures, the IDCP distinguished the clinical sample with PD from the non-clinical sample. The study also suggested the effectiveness of the IDCP to discriminate the profile of the Avoidant and Dependent disorders from the profile of those patients without these diagnoses. The other categories of PD assessed in this study showed profiles that were not statistically divergent, which was probably due to sample size. In a qualitative analysis, however, it was observed that the most expressive dimensions of these profiles proved to be consistent with the conceptual definition of the assessed categories, and also with the definition of the categories that presented comorbidities with these disorders in the sample, conferring criterion validity evidence to the IDCP.

In the present study, only the group with Avoidant disorder presented participants with an exclusive diagnosis in this category, and it is possible to draw a profile that is closer to the prototype for this group. The other profiles shown in this study did not describe a profile that was prototypical of the evaluated diagnostic category, but complex functioning patterns characterized by the association of different personality disorders.

It was observed, empirically, in this clinical study, that the categorical model of classification of PD produces high prevalence of comorbid diagnoses, as pointed by the literature (Brown \& Barlow, 2005; First et al., 2004; Kupfer et al., 2002; Widiger \& Samuel, 2005; Widiger \& Trull, 2007; Zimmerman, 2012). These results emphasize the criticism regarding the reduced scope and poor specificity of categorical diagnoses of PD (First et al., 2004; Hopwood et al., 2011; Widiger \& Trull, 2007).

The wide range of personality disorders in clinical practice reiterates the need for more comprehensive classifications that cover the heterogeneity among individuals who share the same diagnostic category, facilitating the understanding of pathologic personality traits and contributing to clinical decision-making. The diagnostic profiles of PDs generated by the IDCP described subtypes of PDs that could not be discriminated through categorical assessment. The Avoidance of criticism dimension (F9), for instance, proved to be intense in all raised profiles, including the paranoid and borderline groups, for which Avoidance of Criticism is a less expected trait. These profiles are similar to the descriptions of Millon et al. (2004), which described variants of the main pathological patterns of personality such as the Retracted paranoid subtype, which combines the standard paranoid pattern to the standard Avoidant pattern and the Discouraged Borderline variant, an association between the Borderline pattern and avoidant aspects.

In the present study it was also found that among the evaluated psychotherapy outpatients, the Borderline and Paranoid profiles did not show severe scores in dimensions
Aggressiveness (F2), Impulsivity (F12), and Grandiosity (F7), despite having higher scores in these dimensions when compared to non-paranoids and non-Borderlines. These results show that it is essential that diagnostic measures not only clarify in which areas of personality lies the difficulty, but also and especially, what is the severity of this disease, indicating the prognosis of the presented dysfunction and giving subsidies to deliberate on the level of therapeutic attention required. The dimensional assessment indicates the severity of personality disorders, which, according to Hopwood et al. (2011), is an important predictor of the current and prospective dysfunction of personality.

It was also observed that the presence of comorbid diagnoses made the profile on the IDCP significantly more severe and complex. This result is in agreement with the observations by Bender, Morey and Skodol (2011), and Morey et al. (2011) which sought to identify a central dimension of personality pathology involving losses in the functioning of the self and in the interpersonal capacity and found that the greater the number of comorbidities between the PDs, the greater the severity of this central dimension of personality pathology. Finally, the results suggest that perhaps an approach that covers other elements besides that of the categorical proposal would be appropriate; such as it is in the section 3 of the DSM-5 (APA, 2013).

Given the data found, we considered that we reached the objective of the present study, i.e., to look for evidence of validity based on external criteria, specifically psychiatric disorders, for the dimensions of the IDCP. The dimensions that best discriminated each of the four categories of PD were Avoidant subjects who had higher scores on the Avoidance Reviews (F9), moderate scores in Dependence (F1) and lower scores in Need for Attention (F5). Paranoid individuals tended to have higher scores for Distrust (F6), Eccentricity (F4), humiliation and criticism beliefs (F9), Isolation (F8), and Mood Instability (F3). The dimensions Aggressiveness (F2) and Grandiosity (F7) discriminated the Paranoid from the non-paranoid even though there were no high scores in the present sample. Borderline individuals showed high and discrepant scores in Mood Instability (F3), in Eccentricity (F4), and in Isolation (F8). It is suggested that the dimensions Impulsivity (F12), Aggressiveness (F2) and Grandiosity (F7) were also relevant to this category, because they discriminated the Borderlines from non-Borderlines despite not showing too intense in the borderline sample. Also, Dependent individuals presented means that were indicative of severe pathology in Dependence (F1) and Avoidance of Criticism (F9) and high scores in self-sacrifice (F10). These data suggest evidence of validity for the IDCP dimensions as they were consistent with the descriptions of the PDs.

It is noteworthy that despite the discriminations found between the groups of patients, it is necessary that other studies replicate the data of the present one, as part of the observed results may be due to measurement error. The sample size, and the non-contemplation of all PDs may be 
limitations of the present study; therefore, it is suggested that future studies seek to investigate the profiles of the other PDs, with more homogenous clinical samples.

\section{References}

Alvarenga, M. A. S., Flores-Mendoza, C. E., \& Gontijo, D. F. (2009). Evolução do DSM quanto ao critério categorial de diagnóstico para o distúrbio da personalidade antissocial. Jornal Brasileiro de Psiquiatria, 58(4), 258-266. doi:10.1590/S0047-20852009000400007

American Psychiatric Association. (1952). Diagnostic and statistical manual of mental disorders. Washington, DC: American Psychiatry Association.

American Psychiatric Association. (1968). DSM-II: Diagnostic and statistical manual of mental disorders (2nd ed.). Washington, DC: American Psychiatry Association.

American Psychiatric Association. (1980). DSM-III: Diagnostic and statistical manual of mental disorders (3rd ed.). Washington, DC: American Psychiatry Association.

American Psychiatric Association. (1987). DSM-III-R: Diagnostic and statistical manual of mental disorders (3rd ed., rev.). Washington, DC: American Psychiatry Association.

American Psychiatric Association. (1995). DSM-IV: Manual diagnóstico e estatístico de transtornos mentais (D. Batista, Trans., 4th ed.). Porto Alegre, RS: Artes Médicas.

American Psychiatric Association. (2013). DSM-5: Diagnostic and statistical manual of mental disorders (5th ed.). Washington, DC: American Psychiatry Association.

Andreasen, N. C., \& Black, D. W. (2009). Introdução à psiquiatria (M. F. Lopes \& C. Dornelles, Trans., 4th ed.). Porto Alegre, RS: Artmed.

Associação Psiquiátrica Americana. (2002). DSM-IV-TR: Manual diagnóstico e estatístico de transtornos mentais: Texto revisado (C. O. Dornelles, Trans., 4th ed. rev.). Porto Alegre, RS: Artmed.

Bender, D. S., Morey, L. C., \& Skodol, A. E. (2011). Toward a model for assessing level of personality functioning in DSM-5, part I: A review of theory and methods. Journal of Personality Assessment, 93(4), 332-346. doi:10.1080/00223891.2011.583808

Bornstein, R. F. (2011). Toward a multidimensional model of personality disorder diagnosis: Implications for DSM-5. Journal of Personality Assessment, 93(4), 362-369. doi:10.1080/00223891.2011.577474

Brown, T. A., \& Barlow, D. H. (2005). Dimensional versus categorical classification of mental disorders in the fifth edition of the diagnostic and statistical manual of mental disorders and beyond: Comment on the special section. Journal of Abnormal Psychology, 114(4), 551-556. doi:10.1037/0021-843X.114.4.551
Carvalho, L. F. (2014). Avaliação dos transtornos da personalidade no Brasil: O Inventário Dimensional Clínico da Personalidade. In C. R. Campos \& T. C. Nakano, Avaliação psicológica direcionada a populações especificas: Técnicas, métodos e estratégias (pp. 20-30). São Paulo, SP: Vetor.

Carvalho, L. F., Oliveira Filho, A. Q., Pessoto, F., \& Bortolotti, S. L. V. (2014). Application of the unfolding model to the aggression dimension of the Dimensional Clinical Personality Inventory (DCPI). Revista Colombiana de Psicología, 23(2), 339-349. doi:10.15446/rcp.v23n2.41428.

Carvalho, L. F., \& Primi, R. (2015). Development and internal structure investigation of the Dimensional Clinical Personality Inventory (DCPI). Psicologia: Reflexão e Crítica, 28(2), 213-221. doi:10.1590/1678-7153.201528212

Carvalho, L. F., \& Primi, R. (in press). Prototype matching of personality disorders with the Dimensional Clinical Personality Inventory. Psicologia: Teoria e Pesquisa.

Carvalho, L. F., Primi, R., \& Stone, G. E. (2014). Psychometric properties of the Inventário Dimensional Clínico da Personalidade (IDCP) using the Rating Scale Model. Avances en Psicología Latinoamericana, 32(3), 433-446. doi:10.12804/apl32.03.2014.09

Del Porto, J. A. (1996). Transtornos da personalidade. In O. P. Almeida, L. Dratcu, \& R. Laranjeira, Manual de psiquiatria (pp. 180-186). Rio de Janeiro, RJ: Guanabara Koogan.

First, M. B., Gibbon M., Spitzer, R. L., Williams, J. B. W., \& Benjamin, L. S. (2008). Entrevista estruturada para transtornos de personalidade do DSM-IV, SCID-II (1,0): Versão brasileira (N. M. M. Melo \& B. P. Rangé, Trans.). Rio de Janeiro, RJ: sem editora. (Original work published 1997)

First, M. B., Pincus, H. A., Levine, J. B., Williams, J. B. W., Ustun, B., \& Peele, R. (2004). Clinical utility as a criterion for revising psychiatric diagnoses. The American Journal of Psychiatry, 161(6), 946-954. doi:10.1176/appi.ajp.161.6.946

Hopwood, C. J. (2011). Personality traits in the DSM-5. Journal of Personality Assessment, 93(4), 398-405. doi:10.1080/00223891.2011.577472

Hopwood, C. J., Malone, J. C., Ansell, E. B., Sanislow, C. A., Grilo, C. M., McGlashan, T. H., ... Morey, L. C. (2011) Personality assessment in DSM-V: Empirical support for rating severity, style, and traits. Journal of Personality Disorders, 25(3), 305-320. doi:10.1521/pedi.2011.25.3.305

Hopwood, C. J., Thomas, K. M., Markon, K. E., Wright, A. G. C., \& Krueger, R. F. (2012). DSM-5 personality traits and DSM-IV personality disorders. Journal of Abnormal Psychology, 121(2), 424-432. doi:10.1037/a0026656 
Krueger, R. F., Derringer, J., Markon, K. E., Watson, D., \& Skodol, A. E. (2012). Initial construction of a maladaptive personality trait model and inventory for DSM-5. Psychological Medicine, 42(9), 1879-1890. doi:10.1017/S0033291711002674

Krueger, R. F., \& Eaton, N. R. (2010). Personality traits and the classification of mental disorders: Toward a complete integration in DSM-V and an empirical model of psychopathology. Personality Disorders: Theory, Research, and Treatment, 1(2), 97-118. doi:10.1037/a0018990

Krueger, R. F., Eaton, N. R., Derringer, J., Markon, K. E., Watson, D., \& Skodol,A. E. (2011). Personality in DSM-5: Helping delineate personality disorder content and framing the metastructure. Journal of Personality Assessment, 93(4), 325-331. doi:10.1080/00223891.2011.577478

Kupfer, D. J., First, M. B., \& Regier, D. A. (Eds.). (2002). A research agenda for DSM- $V$. Washington, DC: American Psychiatric Association. Retrieved from http://contextualscience.org/system/files/ Kupfer,2002.pdf

Miguel, F. K., Finoto, B. A. S., \& Miras, B. D. (2013). Percepção emocional e traços de personalidade: Estudo de validade divergente. Encontro: Revista de Psicologia, 16(24), 107-120. Retrieved from http://sare.anhanguera. com/index.php/rencp/index

Millon, T. (2011). Disorders of personality: Introducing a DSM/ICD spectrum from normal to abnormal (3rd ed.). Hoboken, NJ: Wiley.

Millon, T., Millon, C. M., Meagher, S., Grossman, S., \& Ramnath, R. (2004). Personality disorders in modern life (2nd ed.). Hoboken, NJ: Wiley.

Morey, L. C., Berghuis, H., Bender, D. S., Verheul, R., Krueger, R. F., \& Skodol, A. E. (2011). Toward a model for assessing level of personality functioning in DSM-5, part II: Empirical articulation of a core dimension of personality pathology. Journal of Personality Assessment, 93(4), 347-353. doi:10.1080/00223891.2011.577853

Oldham, J. M., Skodol, A. E., Kellman, H. D., Hyler, S. E., Rosnick, L., \& Davies, M. (1992). Diagnosis of DSM-III-R personality disorders by two structured interviews: Patterns of comorbidity. The American Journal of Psychiatry, 149(2), 213-220. doi:10.1176/ajp.149.2.213

Patton, M. Q. (2002). Qualitative research and evaluation methods (3rd ed.). Thousand Oaks, CA: Sage.

Skodol, A. E., Bender, D. S., Oldham, J. M., Clark, L. A., Morey, L. C., Verheul, R., ... Siever, L. J. (2011). Proposed changes in personality and personality disorder assessment and diagnosis for DSM-5, Part II: Clinical application. Personality Disorders: Theory, Research, and Treatment, 2(1), 23-40. doi:10.1037/a0021892
Skodol, A. E., Clark, L. A., Bender, D. S., Krueger, R. F., Morey, L. C., Verheul, R., ... Oldham, J. M. (2011). Proposed changes in personality and personality disorder assessment and diagnosis for DSM-5, Part I: Description and rationale. Personality Disorders: Theory, Research, and Treatment, 2(1), 4-22. doi:10.1037/a0021891

Tabachnick, B. G., \& Fidell, L. S. (2007). Using multivariate statistics (5th ed.). Boston, MA: Allyn \& Bacon.

Urbina, S. (2007). Fundamentos da testagem psicológica (C. Dornelles, Trans.). Porto Alegre, RS: Artmed.

Widiger, T. A. (2011). A shaky future for personality disorders. Personality Disorders: Theory, Research, and Treatment, 2(1), 54-67. doi:10.1037/a0021855

Widiger, T. A., \& Samuel, D. B. (2005). Diagnostic categories or dimensions? A question for Diagnostic and Statistical Manual of Mental Disorders-fifth edition. Journal of Abnormal Psychology, 114(4), 494-504. doi:10.1037/0021-843X.114.4.494

Widiger, T. A., \& Trull, T. J. (2007). Place tectonics in the classification of personality disorder: Shifting to a dimensional model. American Psychologist, 62(2), 71-83. doi:10.1037/0003-066X.62.2.71

Zimmerman, M. (2012). Is there adequate empirical justification for radically revising the personality disorders section for DSM 5? Personality Disorders: Theory, Research, and Treatment, 3(4), 444-457. doi:10.1037/a0022108

Roberta Katz Abela is a Psychologist of the Escola Paulista de Medicina, Universidade Federal de São Paulo.

Lucas de Francisco Carvalho is a Professor of the Universidade São Francisco.

Sabrina Jisun Myung Cho is an undergraduate medical student of the Escola Paulista de Medicina, Universidade Federal de São Paulo.

Latife Yazigi is an Associated Professor of the Escola Paulista de Medicina, Universidade Federal de São Paulo.

Received: Sep. 23, 2014

1st Revision: Jan. 28, 2015

Approved: Feb. 2, 2015

How to cite this article:

Abela, R. K., Carvalho, L. F., Cho, S. J. M., \& Yazigi, L. (2015). Validity evidences for the Dimensional Clinical Personality Inventory in outpatient psychiatric sample. Paidéia (Ribeirão Preto), 25(61), 221-228. doi:10.1590/1982-43272561201510 